\title{
Planning Public Debate: Beyond Entrenched Controversies About Islam
}

\begin{abstract}
The contentious public debates about Islam in Scandinavia may to some extent be characterized as an entrenched conflict, upheld by stereotypical framings and fixed rhetorical positions. This case study examines public service media's ability to facilitate public debates that move beyond such ingrained positions. Through interviews with key professionals behind the TV documentary Rebellion from the Ghetto, we examine the strategies for generating public debate about cultural and religious problems. We furthermore analyse online and offline debates, with particular focus on the inclusion of minority voices and how framings of religion enter and influence the discussion. By consciously downplaying the role of 'religion' and framing conflicts in terms of personal experiences and universal themes, the documentary managed to set the scene for a debate in which young Muslims' various experiences were given authority, thereby allowing the debate to transcend the usual 'us-them', 'majority-minority' framing of these issues.
\end{abstract}

Keywords: debate, Facebook, Islam, minority voices, public service

\subsection{Introduction}

In this chapter, we address the role of public service media in generating and facilitating public discussions about controversial issues related to Islam in Denmark. Existing research has often demonstrated that news media tend to focus on religious conflicts and frame Islam in stereotypical ways that may reinforce rigid juxtapositions between the majority of ethnic Danes, 'us', versus the ethnic minority of immigrants with a Muslim background, 'them' (Madsen 2002; Yilmaz 2016). As a result, news media may at times reproduce and reinforce existing discourses and conflicts among ethnic Danes and Muslim immigrants rather than challenge these entrenched positions. Research into public opinion concerning Islam also reveals that critical attitudes towards Islam are not only or primarily a feature of media discourses. Both in Denmark and other Scandinavian countries, a majority of citizens feel that Islam poses a threat to their national culture (Lundby et al. 2017). We should take care to not regard this opinion as synony-

Ә OpenAccess. (c) 2018, Stig Hjarvard, Mattias Pape Rosenfeldt. (cc) BY-NC-ND This work is licensed under the Creative Commons Attribution-Non Commerical-NoDerivs 4.0 License. 
mous with a general resentment towards immigrants since a majority of citizens who consider Islam a threat to their national culture do not endorse hostility towards foreigners. That said, public criticism of Islam has been actively used by right-wing populist parties in all Scandinavian countries to mobilize against immigration in general and from Muslim countries in particular. This political strategy has been fairly successful, with the result that over the past couple of decades, populist parties have become major political parties in Scandinavian parliaments (although with different roles in the individual countries) and have exerted issue ownership over the immigration agenda (Rydgren 2011; Lindroth 2016). In light of this and other major political conflicts that have become intertwined with the immigration issue, such as the international war on terror and the Muhammad cartoon crisis, most of the mainstream political parties in Denmark and other Scandinavian countries have gradually adopted more critical attitudes towards immigration in general and Islam in particular.

It is against this backdrop that we wish to examine whether and how it is possible to engage the public in discussing potentially controversial issues involving Islam and Muslim immigration without necessarily reproducing stereotypes of Muslims among ethnic Danes. We do not aim to provide yet another analytical 'deconstruction' of existing dominant discourses and media's role in reproducing negative stereotypes but seek instead to thread a more 'constructive' path. On the basis of a single case study, we examine how conscious awareness of the existing discursive landscape and deliberate debate planning may play important roles in creating public debates that move beyond entrenched positions concerning religion, Islam, and immigration. Specifically, we examine the television documentary series Rebellion from the Ghetto (Oprør fra ghettoen), broadcast in 2015 by the Danish public service broadcaster DR on its niche channel DR2. The documentary tells the stories of four ethnic minority youths and their relationships to the cultural and religious norms of their parents' generation. The documentary generated public debate across various media platforms, focusing on controversial topics, such as concealed love affairs and homosexuality as well as broader debates concerning the role of minorities and minority religion in Danish society.

In our analysis of the public debate, we look at the interlocking of a generalized public sphere constituted through mass media and a series of sub-publics, which are often articulated through various social network media such as Facebook. We wish to study how discussions in both mass media and social network media framed the problems presented in the documentary series and to what extent discussions also involved a more diverse set of voices, including ethnic minority voices. To summarize, our three main research questions are as follows: (1) What are the intentions and strategies of the producers (the commissioning 
broadcaster DR and the production company Plus Pictures) in terms of generating and moderating public debates about religious and cultural problems? (2) To what extent did the public debate involve ethnic minority participants? (3) Which framings became prominent in the debate following the documentary series $R e$ bellion from the Ghetto?

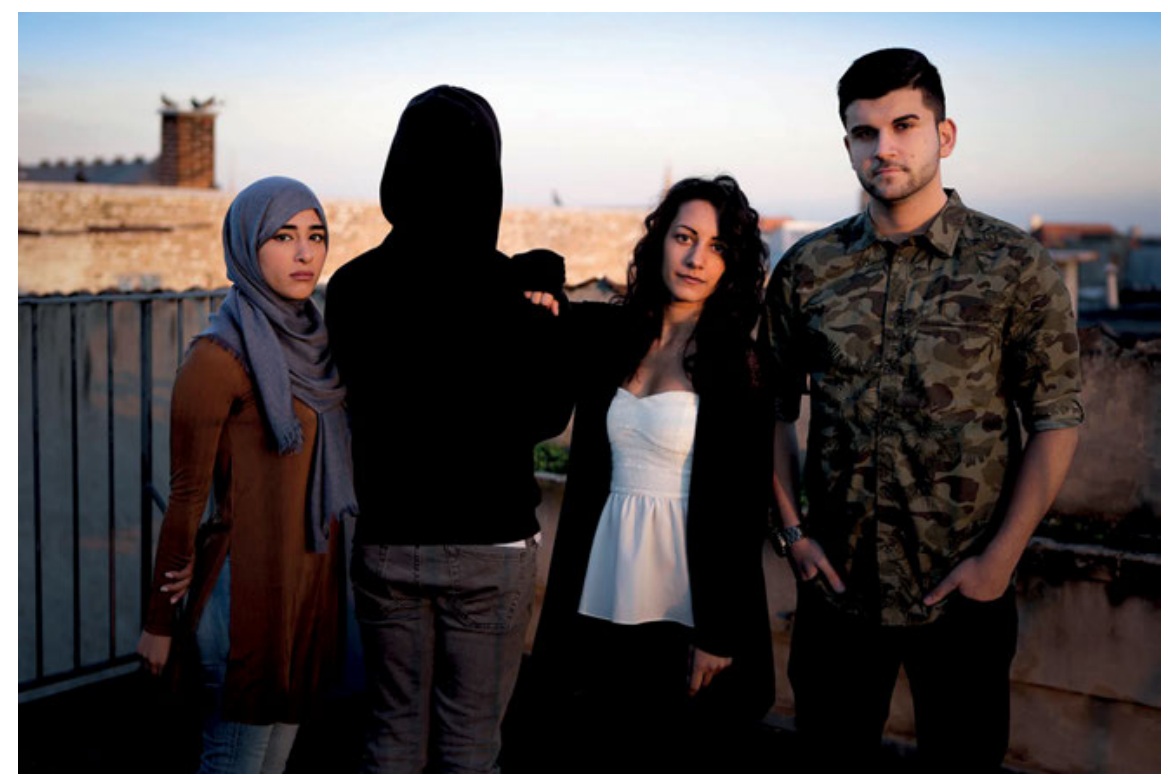

Figure 7.1 New voices in Danish television. Saja, 'Sami', Muna, and Moe from the Danish television documentary series Rebellion from the Ghetto. It was produced by Plus Pictures and broadcast on DR2 in 2015. 'Sami' appeared anonymously in the programme. (Photo: Plus Pictures / Photographer: Simon Dixgaard.)

Methodologically, the study is based on qualitative and semi-structured research interviews (Kvale 1996) and textual framing analysis (Entman 1993) of the debate in publicly accessible media. The analysis builds upon a theoretical typology of mediatized conflicts (Hjarvard, Mortensen, and Eskjær 2015; see Chapter 3) that highlights the role of media in framing and co-structuring conflicts. In the case of Rebellion from the Ghetto, the mediated debate involved not only particular framings of religious and cultural conflicts but also conscious efforts by the producers to take into account pre-existing public framings of contentious issues, which to some extent enabled them to co-structure the discussions beyond entrenched positions of existing debates about Islam. 
The programme and our analysis also address the borders between religion and culture. Ever since Clifford Geertz' (1966) work on religion and culture, it has been common in scholarly circles to view religion as a dimension of culture. A more popular understanding may regard religion as distinct from culture, distinguishing between what is true, essential, and eternal (e.g. Islamic religion) and what is manmade, contextual, and historical (e.g. Islamic culture). However, in the public debate on Rebellion from the Ghetto, such clear distinctions do not seem to exist. To the contrary, the two concepts are often used interchangeably and as containers for the same content. This may in part be a result of the documentary series' initial framing of problems as secular, cultural, and universal, rather than as religious and specific.

\subsection{Producer Intentions}

In December 2015 and January 2016, we carried out four interviews with key actors involved in the production of and public communication surrounding Rebellion from the Ghetto. The interviews focused on expectations, intentions, and relationships in the production phase as well as evaluations of the effects and the roles of various actors in the debate. From the production company, we interviewed one of the two directors, Louise Detlefsen, as well as producer Mette Heide. The communication specialist Line Bilenberg, who was hired externally to promote the documentary, was our third informant. We also interviewed DR senior editor and head of documentaries Mette Hoffmann Meyer, focusing on DR's role in the initial production phase and public discourse surrounding $R e$ bellion from the Ghetto.

The DR editor provided the initial idea for the documentary, wishing to explore what she perceived as a more general problem of social control and everyday violence in immigrant families. She got the inspiration for this topic and framing from the poems of the young Danish writer Yahya Hassan, who has fiercely criticized the parental generation of immigrants in Denmark on the basis of his own experience (Hassan 2013). Despite Hoffmann Meyer's power as commissioning editor, the relative autonomy of the production company should not be overlooked. The initial objectives of the documentary seem to have gradually changed after the project was adopted by Plus Pictures. Executive producer Mette Heide describes a process in which the directors - through a lengthy and 'academic' research process - developed a more nuanced understanding of the social reality they intended to describe. Heide continues: 
[The directors] were casting and talking to people, and in their 'fieldwork' they could see there were softer values and some themes that would be relevant for a larger group of people, namely who you can partner up with in your love life. As directors of the documentary, they were very clear on this. It's of no use if we make another 'us versus them' story with this violent image of immigrant culture. It's important that we make a film where they [the ethnic minority youth] can recognize themselves and that at the same time gives insight for Danish-Danish viewers. You might say we changed what we'd originally been asked to produce along the way.

Producer, Mette Heide, Plus Pictures. Interviewed by authors on 18 December 2015

The production company did not, however, have completely free rein, and the commissioning editor interfered when she found it necessary. This became particularly clear when deciding on the title of the series, with the DR editor insisting on Rebellion from the Ghetto. No one from the production company was happy with this title since it revived negative 'us versus them' stereotypes, but they had to live with it. This disagreement about the title reveals DR's 'business as usual' logic when it comes to representing Islam and Muslims. The DR editor does speak of approaching the topic with an open mind, but her focus is the conflict between immigrant, minority norms and those of the majority society. In contrast, the directors are more interested in making a television series in which the conflicts take on a universal character concerning love, sex, and generational conflict while differences between majority and minority groups become less divisive.

DR has a longstanding professional relationship with independent production companies, including this company, Plus Pictures. In the case of Rebellion from the Ghetto, we see a dynamic relationship between DR and Plus Pictures, with the public service broadcaster taking part in several steps of shaping and producing the documentary. Plus Pictures naturally influences the shaping of the programme, but we also see the production company playing an important role in orchestrating initiatives designed to generate public debate about the themes of the documentary series. It is important to note that the professionals in question from Plus Pictures articulate a strong personal commitment to public service values: Public service ideals seem just as deeply embedded in the private company as in the public organization.

\subsection{Talking About Islam}

The director of the documentary Louise Detlefsen says that the team was 'talking a lot about religion [Islam]' throughout the production. There is clear awareness that Islam is a controversial and difficult subject. In the eyes of the production 
team, the main difficulty seems to be the polarized range of pre-existing stances that dominate public conversations about Islam - Islamists on the one side and Islam-bashers on the other - and that it is hard to avoid being pushed into one of these positions. The communication specialist Line Bilenberg argues that it was important to deal with this problem in advance in a very explicit way when talking to the various people involved in the documentary: 'If there's an elephant in the corner of the room, then say it. Don't pretend it's not there. So, say it out loud: "My biggest fear is that this is going to be about Islam".' The young characters in the film did not want their problems to be interpreted in light of Islam and instead regarded problems with their parents and wider social network as cultural issues. The production team wanted to replace the scornful criticism of first-generation immigrant parents they had experienced in, for instance, the poems of Yahya Hassan with a more mature and nuanced critique. In the eyes of the communication specialist, this was the documentary's new and ground-breaking feature: The main characters take centre stage as (part of) the rational and compassionate mainstream 'we', instead of standing outside as either victims or aggressors. The strategy was to focus on showing the participants' problems as more general - or even universal - instead of something specific to Muslims. This approach was designed to create space for a conversation that would be less easily hijacked by the usual polemic positions in the debate about Islam.

DR editor Mette Hoffmann Meyer does not have the same concerns. She is not particularly interested in downplaying the role of Islam and religion but instead simply states that she tries 'to treat this as I would any other topic', tying this to general claims of balance and impartiality. Furthermore, she explicitly distances herself from activist documentary films with a particular message, which seek to persuade audiences to think in particular ways:

I actually don't believe activist documentary films have any great impact. If you sense right from the start that there's a hidden agenda, or as often the entire programme is cut to make you stop eating pork or drinking French wine, you get bored and intimidated. Do they think I am stupid, or what? If you make activist film, you want to twist the story to brainwash the viewer - want to guide people toward something in particular. I actually don't think activism is a public service role. I think we need to create knowledge and understanding and insight. And then, I suppose, it's up to the individual to take a position on it. Perhaps even seek further knowledge. In other words, I believe in making people curious and asking 'Why?'

Senior Editor Mette Hoffmann Meyer, DR. Interviewed by authors on 1 December 2016

The production team from Plus Pictures does not necessarily disagree with this. Executive producer from the production company, Mette Heide, supports an im- 
partial position, saying 'we're not promoting any particular position' and 'you can't - and shouldn't - try to control and manipulate opinion'. She thus positions herself between a traditionalist and impartial role of public service broadcasting as merely a forum for public debate and a more activist conception of public service media as an actor that intervenes to make a difference in public debate. This latter position does not necessarily entail that the television series carries a persuasive message, which is what DR's editor argues against. The activist position does, however, seek to engage audiences to discuss problematic issues in new ways.

\subsection{Engaging the Audience: Building Public Debate}

The director and the communication specialist are strikingly clear in their explanations of the purpose of the programme. The programme seeks to engage ethnic minority youth in the debate surrounding the themes of the documentary: homosexuality and individual freedom to choose the partner you want. Bringing these themes to the ethnic youth and engaging them in dialogue became the documentary's raison d'étre for director Louise Detlefsen:

\footnotetext{
It wasn't the typical DR2 audience we were looking for. It's wonderful that the programme is shown on the Danish TV channel DR2, and they are the ones we produced it for, etc. But clearly, our own motivation was that it was the young people with a non-Danish ethnic background who we wanted to talk about these themes. We wanted to have a discussion internally. Could we start a conversation? This was clearly what we wanted to do.
}

Director, Louise Detlefsen, Plus Pictures. Interviewed by authors on 18 December 2015

On a more general note, the director points out that the interest in ethnic minority youth and Islam comes from a general social commitment, and it is in a sense 'accidental' and comparable with the interest she has in other social issues, such as poverty.

The producer is largely in agreement with the director on this issue. A freelance communication specialist was hired to plan and organize the debate, and with special focus on moving it into the realms of Danish ethnic minority youth. There were two steps in this strategy. First, to gather a diverse group of existing young ethnic minority debaters (role models) and engage them in debating the themes of the documentary on various media platforms. Second, to arrange a series of screenings of the documentary in typical 'ghetto areas', thereby taking the debate back to the environment the documentary explores. Engagement with 
the ethnic minority community was important for the subsequent marketing of the television series and the framing of the debates following the broadcast. This priming of ethnic minority opinion leaders to engage with the issues raised by the television series ensured there would be people and arguments to build upon when the programmes were eventually broadcast and when the debate in the general news media and social media took off. As communication specialist Bilenberg states, 'you can't set an agenda if only the media write about it, and no one pays attention to it in social media. You can't set the agenda if you only have what is called a journalistic approach. You also need to have debaters or politicians or some other people'. The initial screenings with young ethnic debaters also allowed Bilenberg to get an early account of possible frames and criticism that could arise when the programme was broadcast. On this basis, she was better equipped to stimulate the subsequent debate in line with the original intentions of Plus Pictures.

Curiously, the strategy was based not only on a professional evaluation of how to maximize the programme's reach but also fuelled by personal frustration on the part of key members of the production team. This sense of indignation seemed to drive even the communication specialist in her professional efforts:

Both instructors felt... - and I felt - an indignation that we haven't got any further [with integration]. It's important that these [young ethnic minority] voices come out. Quite simply, because they're voices we've lacked in the debate. If we can reach out to this target group, the effect will be that it may be more legitimate to talk about these things. So it's a huge help. This thing when something is being said on TV - nationwide - that you in one way or another suddenly create a space where it's permitted to talk about things.

External communications specialist Line Bilenberg. Interviewed by authors on 7 January 2016

The statement by Bilenberg also bears witness to the strategy of using the authority of television to create space for discussions in civil society, both online and offline. The aim was thus less to attract the attention of political decision makers than to allow new voices to emerge.

In addition to the task of stimulating debate in general, the communication specialist was hired to take care of various forms of crisis communication. Experiences from other Plus Pictures productions had shown that debates could become very harsh, including hate mail and death threats targeted at the main characters in the documentary. Especially when dealing with young and nonprofessional sources, it is important to have a support function for these kinds of debates, including professional advice for the characters about when to engage - or not engage - in social media debates. As a whole, the production company's strategy seems to reflect a public service ethos of a more activist variety; it 
is less concerned with usual parameters of success in the broadcasting industry, such as higher viewer ratings (popularity) and professional recognition. Instead, the strategy bears witness to a much more idealistic approach and suggests a conviction that the documentary can initiate real societal change.

\subsection{Minority Voices in the Debate}

The critical question is, then, to what extent the television series managed to create a public debate in mainstream news media and social network media with a greater representation of minority actors' voices (MAV). In this analysis, we distinguish between strong and weak MAV representation. Inspired by Jacobsen et al. (2013), we define strong MAV representation as when the primary actor in the commentary has a visible minority background. In most cases, this is when the author/host has a visible minority background, but we have also coded interview protagonists as strong MAV. Weak MAV is when a minority actor is mentioned and quoted or paraphrased in a comment.

Representation of MAV is often regarded as a measure of media outlets' success at including minorities (Jacobsen et al. 2013). There may, however, be other factors behind a particular frequency of MAV representation than the media's openness to diversity and minorities. Nadim (2017) reports from a Norwegian study that individuals with minority backgrounds do not necessarily find it difficult to access public debate but may nevertheless be reluctant to participate because they are often ascribed a fixed role in such contexts as being representative of a particular minority group. Based on these insights, we propose a theoretical understanding of MAV representation that takes into account the willingness of and ability for minority voices to make themselves heard.

We use a recent study of news and current affairs debates about Islam and Muslims as a benchmark for comparing the representation of minority voices in the debates about Rebellion from the Ghetto with the more general pattern of MAV representation. In their study of minority actor voices in four Danish newspapers' coverage of Islam, Muslims, and racism, Jacobsen et. al. (2013) find 11 percent weak MAV representation and 13 percent strong MAV representation, resulting in a total of 24 percent MAV representation. The study concludes that 'the reporting was rather one-sided and exclusive of minority voices, and when Muslims were given voice, the same few publicly visible and vocal actors appeared. At the same time, the lives and opinions of the less visible majority of Muslims more or less vanished in the Media coverage' (Jacobsen et al. 2013, 53). Not only were no minority actors represented in three-quarters of the articles about Islam, 
Muslims, and racism, but news media seem to present a narrow range of minority sources.

In order to acquire an overall understanding of the media debate, we screened and collected material from a broad range of online, broadcast, and print media, compiling a sample of debate and opinion pieces explicitly addressing Rebellion from the Ghetto. We found relevant material from roughly two weeks leading up the TV premiere at the start of December 2015 until one week into January 2016, thus covering a period of approximately seven weeks. In this period, we registered 10 opinion pieces from six different national print papers. From broadcast radio, we look at three long-format debates. One of these is from DR and has a general reputation of being critical, devoting time to background and counter-perspectives. The other two long-format radio debates were derived from two episodes of Rushy's Roulette, a weekly debate programme focusing on integration and immigrant culture and hosted by the public service Radio 24/7. Our evaluation of the online debate material singled out the official Facebook site of the show Rebellion from the Ghetto (40 posts, 184 comments) as well as from the official site of DR2 (the channel that aired the film; 1 post, 40 comments) and the official Facebook page of the daily newspaper Politiken (1 post, 338 comments) as central online hubs for the public discussion. The Facebook sites were all lightly moderated, e.g. removing hateful commentary.

The coding of MAV representation in the debates about Rebellion from the Ghetto in the printed press and broadcast radio reveals an extraordinarily high representation of minority voices. Table 7.1 shows the representation of minority voices in ten opinion pieces in the press and in three radio debates.

Table 7.1 The distribution of Minority Actors' Voices (MAV) in debates about Rebellion from the Ghetto in the press and broadcast radio.

\begin{tabular}{lll}
\hline & Press (10 items) & Broadcast radio (3 items) \\
\hline Weak MAV & $50 \%$ & $0 \%$ \\
\hline Strong MAV & $40 \%$ & $87 \%$ \\
\hline Total MAV & $90 \%$ & $87 \%$ \\
\hline
\end{tabular}

With nine out of ten of the items including a MAV in the press debate, and with 40 percent having a minority representative as the primary voice, it is clear that MAV representation is high in this part of the debate. A condition of unusually high representation becomes even clearer when we consider the debate in broadcast radio, where nearly nine out of ten debate participants/hosts have minority backgrounds. The debates found online also feature high MAV representation, 
though not quite on the same level as in press and broadcast radio. An analysis of 562 comments from the three Facebook sites in the study show that MAV is represented in well over half the total comments (61.5 percent). On Rebellion from the Ghetto's Facebook site (Oprør fra Ghettoen), MAV representation in 74 percent of the comments is remarkably high, and somewhat comparable to the level in the press debate, whereas the two other websites have MAV representation in approximately half the comments. MAV representation in the online debates is summarized in Table 7.2.

Table 7.2 The distribution of Minority Actors' Voices (MAV) in debates about Rebellion from the Ghetto on three Facebook sites.

\begin{tabular}{lllll}
\hline Facebook pages: & $\begin{array}{l}\text { DR2 } \\
\text { (40 comments) }\end{array}$ & $\begin{array}{l}\text { Politiken } \\
(338 \text { comments) }\end{array}$ & $\begin{array}{l}\text { Oprør fra Ghettoen } \\
(\mathbf{1 8 4} \text { comments) }\end{array}$ & $\begin{array}{l}\text { All } \\
\text { (562 comments) }\end{array}$ \\
\hline Weak MAV & $5 \%$ & $1 \%$ & $20 \%$ & $7.5 \%$ \\
\hline Strong MAV & $45 \%$ & $55 \%$ & $54 \%$ & $54 \%$ \\
\hline Total MAV & $\mathbf{5 0 \%}$ & $\mathbf{5 6 \%}$ & $\mathbf{7 4 \%}$ & $\mathbf{6 1 . 5} \%$ \\
\hline
\end{tabular}

The debate about Rebellion from the Ghetto has a significantly higher occurrence of minority actors' voices compared with in the average news and current affairs debate. We note that the established and edited media outlets (the daily press and broadcast radio) have a significantly higher number of minority actors' voices than we find on broad spectrum Facebook pages. Also, when considering the 'public visibility' of the actors present in the debate, it is clear that many new voices are making themselves heard, especially online, where only few of the minority voices contributing to the debate are individuals who are familiar from the ongoing public debate. It is also interesting to note that, in quite a few of these online and radio conversations between different minority actors, we find no non-MAV participants. The public service radio debates presenting a full panel of ethnic minority voices are good examples of this. The result is a debate that, at least on a structural level, challenges traditional 'us versus them' and 'majority-minority' juxtapositions.

\subsection{Public Debate About Rebellion from the Ghetto}

In order to analyse the main arguments and discursive positions in the various debates, we apply framing theory as developed by Entman (1993) and others. Ac- 
cording to Entman (1993), frames provide texts with a specific perspective by implicitly or explicitly proposing a problem definition, causal interpretation, moral evaluation, and/or treatment recommendation. We distinguish between two types of framings, each operating at a different level of generalization: specific frames and general frames. Specific frames are more definitive articulations of 'problems', 'explanations', 'moral evaluations', 'recommendations for action', or any combination of these. Since our textual material in some cases includes very short interventions, it is not possible to identify all these dimensions in every intervention, and in some cases these dimensions are present in only rudimentary form. General frames are central organizing principles that are socially shared (Reese 2001), i.e. that occur persistently across larger sections of textual discourses and represent a general 'interpretative package' (Gamson and Modigliani 1989). Both general and specific frames are understood as issue-specific frames, in contrast to generic frames that may be used across various thematic domains (de Vreese 2005).

Our textual analysis revealed three general frames in the debate. The first typical general frame is what we have dubbed Immigrant culture (religion) is oppressive. Here we find immigrant culture and/or religion singled out as a critical problem. This problem definition is sometimes substantiated with reference to reports and social research focusing on immigrant ghettos. In other cases, problems are explicitly linked to qualities inherent in the immigrant and/or Muslim culture, thereby explaining the problem with a more explicitly essentialist understanding, as expressed in this letter to the editor from a Berlingske reader:

The young people feel frustrated, split between the interests of their cultural background with a very purely patriarchal, male-dominated culture, and the culture of freedom and independence that we in Denmark are so proud of, and which the young people in the film long to be able to live in.

Jan Hald, 'Integration' letter in Berlingske, 13 December 2015

Some of these specific frames lack solutions to the proclaimed problems of immigrant culture, ending in vague, sometimes sentimental formulations of hope that 'the young Muslims will see change' (P.A. Pedersen 2015) or that they will 'continue so that their children will be able to live the dream we all have' (Hald 2015). The debates do not clearly distinguish between culture and religion; to the contrary these concepts tend to be used interchangeably. This may in part be a result of the documentary series' attempt to downplay the explicitly religious aspects of the issues.

Other comments do come up with solutions or calls to action: One frequent recommendation is that heterogeneous immigrant and religious culture should 
be promoted and accepted more broadly (Piil 2015). This recommendation is perhaps unsurprising, given that it aligns with the central theme of the documentary. Another recommendation for action is part of a recurring theme in the material, namely a meta-perspective in which media involvement is part of the focus. Here it is stated that critical media representation of immigrant culture and Islam is an important tool for countering social problems within immigrant environments. Some of these discussions are remarkably nuanced, weighing and assessing the various arguments. One example is a long post on Rebellion from the Ghetto's Facebook site that acknowledges the generally negative media representation of Islam but also warns against keeping this media critique on autopilot. This post recommends normalization of the representation of Islam and Muslims, and from this follows a reasonable inquiry into, for example, social problems (Oprør fra Ghettoen 2015).

The second general frame precisely concerns media representation of young Muslims. Here the central problem is that the representation of young Muslims in Rebellion from the Ghetto is stereotypical. According to this frame, the television series is basically another victim story, lacking nuance. The story does not make the Danish audience confront its own violence and social control but confirms the fiction that this phenomenon belongs to immigrant families:

Precisely by avoiding the exploration of the nuances, the documentary turns Muna [a central character] into a hand puppet delivering a cliché victim story typical of Danish TV's representation of ethnic minorities. This is sad because [Muna's] story deserves to be told in full, with all its ambivalence and despair. That would generate identification instead of fascinated outrage and might even remind Danish viewers of the power relations in their own families, instead of confirming that social control only exists among Muslims.

Johanne Mygind, 'Egen stemme' in Weekendavisen, 4 December 2015

One solution to this problem is to let the young Muslims represent themselves as artists and producers. Another recommendation is to involve Muslims in the everyday media landscape as subjective individuals with expertise in many other subject areas, such as the economy - and not to constantly single them out as outsiders or 'the other' (Piil 2015). This general frame obviously has a meta-quality as well since it evaluates the media's representation of Islam and Muslims.

The third general frame also has a self-reflexive meta-layer. Here, however, the reflexivity concerns the debate itself. One aspect of this framing focuses on new female voices, which seem more frequent and more diverse. The moral here is that it is important that young women start speaking for themselves in public debates, and the recommendation is for continued recognition and support for this new development. Another aspect of this frame focuses on homo- 
sexuality among immigrants as an important topic. The young ethnic minority homosexuals represent an extremely vulnerable group that can be helped and normalized if the public debate sheds light on this taboo topic. Some debaters also speak of increasing discord among young Muslims. Some Muslim youths take part in shaming and social control of other young Muslims, making their lives miserable:

On the one hand, we find young 'new Danes' who can no longer keep up appearances or
want to compromise their own freedom and liberal rights. And on the other hand, we find
the young 'new Danes' who surpass even their parents' ability to abide by conservative val-
ues, and thereby interpret any deviation from the parents' cultural and religious customs as
a final departure from the tradition. It's the youth rebellion fighting itself.
Geeti Amiri, 'Nydansk ungdomsoprør svigtes af sine egne' in Ekstra Bladet, 7 December
2015

This divide, it is asserted, is a huge problem, obstructing more rapid integration of the young generations. Instead, it is suggested, young Muslims should stand together in solidarity and defend each other's rights to individual choice (Oprør fra Ghettoen 2015). Religion is also considered in this moral evaluation: One debater asserts that the young Muslims who use religious arguments to target documentary participants as sell-outs are in fact being hypocritical: These critics lack real religious conduct or knowledge. Their lack of empathy and solidarity with young peers who are facing social difficulties is disturbing and should be seen for what it is, nasty bullying (M.C. Pedersen 2015). A final aspect of this framing is constituted by new citizen-driven organizations The Neighbourhood Mothers (Bydelsmødrene) and Baba - Fathers for Change (Baba - Fædre for Forandring). Both seek to involve the parental generation in the younger generation's social problems through dialogue. These organizations are typically active in local areas - arranging meetings and community events - but are usually absent from the media debate. They try to make a difference locally, including by recognizing the horizons and sensibilities of the parental generation.

To summarize, the debate that surrounded Rebellion from the Ghetto is characterized by the following: First, we find a relatively limited number of general framings. This testifies to a focused debate that stays on the track proposed by its initiators, although the debate also involves critical voices against the framings of the documentary's producers. Second, there are remarkably few radical and aggressive standpoints. As noted above, the specific topic of integration and Islam is by default synonymous with contentious conflict in the media, and public debates often feature a very aggressive tone. This is not the case for this documentary. The debate about Rebellion from the Ghetto is on the 
whole quite sober. Third, debaters seem interested in discussing how different media and public figures act with regard to religion and minority culture. We call this meta-talk, which is characterized by two aspects in particular: 1) There is a focus on (classic) media representation, typically formulated as a critique of the established media's ability to adequately represent minorities. It should be noted that we also find a defence of the established media's right and duty to scrutinize all citizens regardless of ethnicity or religion. 2) New actors in the debate are highlighted: the young female voices, the sexual minorities, and the parental generation. These new actors in the debate become a separate topic of discussion. Broadcast radio in particular is working on this framing. This brings us to a fourth point: The production team's intentions seem to materialize in reality. There is extensive reflection on the quality and nature of the debate from different angles, and ethnic minority youths play a prominent role in the discussions, often as active protagonists.

\subsection{Conclusion}

Public service media are under special obligations to both engage with critical issues in society and provide forums for informed public debate, and in the case of Danish public service media under a specific obligation to work for integration (see Chapter 5). Often these obligations are fulfilled by communication of already existing critical positions in the debate and giving voice to traditional and well-established voices in the field. As this case study has demonstrated, public service media may also - occasionally - succeed in raising critical issues independently of traditional political actors and at the same time engage other and less frequent heard voices in the debate. To succeed with this in an already established - and to some entrenched - political conflict requires not only an interesting programme with a series of selected and well-researched stories to ground the argument, but also a conscious effort to develop and organize discussions in particular ways among different audiences, online as well as offline, and a strategy to create synergy between debates in different kinds of media and between different actors.

This conscious approach is certainly not a guarantee of success, and the debates surrounding Rebellion from the Ghetto could easily have taken another course. The production team also expresses a certain relief that the debate about the programme was not significantly affected by some of the traditional positions in the public debate concerning Islam and immigration. The producer Mette Heide mentions that if, for instance, the Danish right-wing populist party Dansk Folkeparti had entered the debate, it could have gone in very different di- 
rection. An interesting lesson from the case study seems furthermore to be that, by consciously downplaying Islam as a religion, the series allows discussions to follow a somewhat different path than might otherwise have been the case. The result is not that religion or Islam are neglected in the debate; to the contrary, religious issues are frequently addressed. But because critical issues are not initially framed as a critique of Islam as such, more immigrants with Muslim backgrounds felt inclined to enter the debate.

Our analysis also demonstrates how the mediatized conditions of contemporary cultural and religious conflicts may not only or always deepen conflicts. Through critical awareness of the role of media in public controversy, it is possible to use media to stimulate new ways of engaging with such conflicts. The media dynamics of mediatized conflict, amplification, framing and performative action, and co-structuring (Hjarvard, Mortensen, and Eskjær 2015; see also Chapter 3) can also be mobilized to support a more sensitive and nuanced debate about controversial issues. The advance screening of the documentary series among ethnic minority groups and particularly among individuals with a recognized position within these communities worked to amplify and frame the documentary's arguments in a particular way, which helped set the scene for subsequent interventions. The conscious framing of the problems as not being about religion but as individual, cultural, and universal issues also helped make the debate diverse. The combined professional resources of DR and Plus Pictures allowed these media actors to influence the overall structure of the debate as it occurred in broadcast radio and the documentary's official Facebook page. The public service media's ability to raise such discussions is not limited to factual genres such as documentary but may also involve entertainment genres such as comedy shows (Hjarvard and Rosenfeldt 2017).

The mediatized conditions of the debate were, however, evident to more than just the people behind the documentary. As our framing analysis shows, meta-discussions about the (problematic) role of media in relation to these issues are integral to public discussions about integration and Islam. This reflects a growing public awareness of the mediatized conditions of such conflicts, yet as our analysis demonstrates, these conditions do not necessarily intensify conflicts or get participants to dig deeper into even more entrenched positions. Nevertheless, moving a debate out of entrenched positions requires not only good will but also professional media expertise, resources, and an institutional framework such as public service - that can deploy expertise and resources in practice. 


\section{Bibliography}

Amiri, Geeti. 2015. "Nydansk ungdomsoprør svigtes af sine egne." [The Youth Rebellion of the New Danes is Betrayed by their Own]. Ekstra Bladet, 7 Dec. http://ekstrabladet.dk/ opinionen/geetiamiri/Nydansk-ungdomsopr\%C3\%B8r-svigtes-af-sine-egne/5861555

de Vreese, Claes H. 2005. "News Framing: Theory and Typology." Information Design Journal + Document Design 13 (1): 51-62.

Entman, Robert. 1993. "Framing: Toward Clarification of a Fractured Paradigm.” Journal of Communication 43 (4): 51-58.

Gamson, William A., and Andre Modigliani. 1989. "Media Discourse and Public Opinion on Nuclear Power: A Constructionist Approach." American Journal of Sociology 95 (1): 1-37.

Geertz, Clifford. 1966. "Religion as a Cultural System." In Anthropological Approaches to the Study of Religion, edited by Michael Banton, 1-46. London: Tavistock Publications.

Hald, Jan. 2015. “Integration." Letter to the editor. Berlingske, 13 Dec.

Hassan, Yahya. 2013. Digte. Copenhagen: Gyldendal.

Hjarvard, Stig, Mette Mortensen, and Mikkel F. Eskjær. 2015. "Introduction: Three Dynamics of Mediatized Conflicts." In The Dynamics of Mediatized Conflicts, edited by Mikkel F. Eskjær, Stig Hjarvard and Mette Mortensen. New York: Peter Lang.

Hjarvard, Stig, and Mattias P. Rosenfeldt. 2017. "Giving Satirical Voice to Religious Conflict: The Potentials of the Cultural Public Sphere." Nordic Journal of Religion and Society. 30 (2): 136-152. DOI 10.18261/issn.1890-7008-2017-02-03

Jacobsen, Sara Jul, Tina Gudrun Jensen, Kathrine Vitus, and Kristina Weibelet. 2013. "Analysis of Danish media Setting and Framing of Muslims, Islam and Racism." Working Paper 10: 2013. Copenhagen: SFI (The Danish National Centre for Social Research).

Kvale, Steinar. 1996. Interviews: An Introduction to Qualitative Research Interviewing. Newbury Park, CA: Sage.

Lindroth, Bengt. 2016. Väljarnas hämnd. Populism och nationalism i Norden. [The revenge of the voters. Populism and nationalism in the Nordic countries]. Stockholm: Carlsson

Lundby, Knut, Stig Hjarvard, Mia Lövheim, and Haakon H. Jernsletten. 2017. "Religion Between Politics and Media: Conflicting Attitudes to Islam in Scandinavia." Journal of Religion in Europe 10 (4): 437-456 (open access). DOI: 10.1163/18748929-01004005

Madsen, Jacob G. 2002. Mediernes konstruktion af flygtninge- og indvandrerspørgsmålet. [The Media's Construction of the Refugee and Immigration Issue]. Aarhus: Magtudredningen.

Mygind, Johanne. 2015. "Egen stemme.” [In their own voice]. Weekendavisen, 4 Dec.

Nadim, Marjan. 2017. "Ascribed Representation: Ethnic and Religious Minorities in The Mediated Public Sphere." In Boundary Struggles: Contestations of Free Speech in the Public Sphere, edited by Arnfinn H. Midtbøen, Kari Steen-Johansen, and Kjersti Thorbjørnsrud, 229-256. Oslo: Cappelen Damm Akademisk (open access). https://press. nordicopenaccess.no/index.php/noasp/catalog/book/16

Oprør fra Ghettoen. 2015. Facebook.com. Rebellion from the Ghetto's official movie page. Accessed 29 August 2017. https://www.facebook.com/Oprør-fra-Ghettoen133032013724952/.

Pedersen, Marie C. 2015."Vi er en stærk generation, og vi er villige til et oprør.” [We are a strong generation and we are willing to rebel]. Politiken, 17 Nov. 
Pedersen, Poul A. 2015.”Forbudte følelser i Ghettoland.” [Forbidden feelings in the land of the ghetto]. Politiken, 6 Dec.

Reese, Stephen D. 2001. "Prologue - Framing Public Life: A Bridging Model for Media Research." In Framing Public Life: Perspectives on Media and our Understanding of the Social World, edited by Stephen Reese, Oscar Gandy, and August Grant, 7-31. Mahwah, N.J.: Lawrence Erlbaum.

Piil, Sarah. 2015. "Hvornår ser vi en etnisk minoritetsdansker være økonomiekspert.” [When will we see an ethnic minority Dane as an expert on economy?] Information, 11 Dec.

Rydgren, Jens. 2011. "Radical Right-Wing Populism in Denmark and Sweden: Explaining Party System Change and Stability." The SAIS Review of International Affairs 30 (1): $57-71$.

Yilmaz, Ferruh. 2016. How the Workers Became Muslims: Immigration, Culture, and Hegemonic Transformation in Europe. Ann Arbor: University of Michigan Press. 